\title{
PENGUNGKAPAN IDENTITAS MENTERI PADA MATERI KOMEDI PENTAS DRAMA “PRESTASI TANPA KORUPSI"
}

\section{DISCLOSURE OF MINISTER'S IDENTITY \\ ON THE COMEDY MATERIAL OF "PRESTASI TANPA KORUPSI" DRAMA PERFORMANCE}

\author{
Pandu Pratama Putra \\ Kantor Bahasa Provinsi Kalimantan Timur \\ Jalan Batu Cermin 25, Sempaja Utara, Samarinda, Kalimantan Timur \\ Pos-el: pandu.pratama@kemdikbud.go.id
}

*) Naskah diterima: 3 Maret 2020; direvisi: 3 September 2020; disetujui: 19 Oktober 2020

\begin{abstract}
Abstrak
Komedi memiliki peran penting di dalam kehidupan. Kehadirannya merupakan salah satu cara sederhana untuk membuat komunikasi antarmanusia menjadi lebih lancar. Berkomedi dan menikmati komedi menjadi milik semua orang. Pemerintah juga dapat memanfaatkan komedi sebagai alat mendekatkan diri pada masyarakat seperti yang dilakukan oleh tiga menteri dalam pentas drama "Prestasi Tanpa Korupsi". Penelitian ini bertujuan untuk melihat pembangunan komedi yang dilakukan oleh menteri pada pentas drama "Prestasi Tanpa Korupsi". Pengungkapan identitas pada komedi menggunakan teori praanggapan yang dimiliki ilmu pragmatik. Penelitian ini menggunakan metode kualitatif deskriptif untuk menelaah data rekaman pentas drama "Prestasi Tanpa Korupsi". Penelitian ini mengungkapkan hasil berupa komedi yang dibangun dari identitas ketiga menteri. Komedi dibangun secara sederhana dan dapat diimitasi oleh masyarakat yang awam dalam dunia komedi.
\end{abstract}

Kata kunci: praanggapan, komedi, menteri

\begin{abstract}
Comedy has an important role in life. Its presencenis one of a simple way to easier communicate each other. Comedy also belongs to everyone in the world. There are no restrictions for those who have permission and who do not for doing a comedy. The goverment can also utilize comedy as a tool for being closer to the society, as what the three ministers did on the performance of the drama "Prestasi Tanpa Korupsi". This research aims to see the development of comedy conducted by the Minister on the drama performance of "Prestasi Tanpa Korupsi". Identity disclosure of the comedy using presuppositions theory of pragmatic science. This research used descriptive qualitative method to examine the recording data of "Prestasi Tanpa Korupsi" drama performance. This research reveals the results that the comedy built from the identity of the three ministers. The comedy is built in the simple way and can be imitatated by the common citizens in the comedy.
\end{abstract}

Keywords: presuppositions, comedy, ministry 


\section{PENDAHULUAN}

Tertawa merupakan salah satu perasaan baik yang dimiliki oleh manusia. Tertawa secara normal memberikan manfaat kesehatan. Peneliti Universitas Loma Linda, California menyebutkan bahwa tertawa dapat memperpanjang umur, memperkuat sistem kekebalan tubuh, mengurangi tekanan darah, mengurangi depresi, menyehatkan pernafasan, membantu mengurangi berat badan, dan melindungi jantung (www.kanal.co).

Tertawa tidak hanya dapat menyehatkan tubuh manusia. Tertawa juga berguna dalam interaksi sosial antar manusia. Tertawa bahkan telah dijadikan sebagai salah satu parameter penerimaan seorang individu terhadapindividu lainnya (Setiawan dalam Cahyono, 2002:162). Kesadaran akan pentingnya tertawa yang berpengaruh pada interaksi sosial ini nampaknya disadari oleh pemerintahan Joko Widodo dan Ma'aruf Amin sebagai Presiden dan Wakil Presiden terpilih tahun 2019-2024.

Joko Widodo dan Ma'aruf Amin telah dilantik sebagai Presiden dan Wakil Presiden terpilih dan akan menjabat selama lima tahun. Seiring dengan berakhirnya pemilihan presiden tahun 2019, maka berdampak pula pada kegaduhan yang terjadi di masyarakat. Perbedaan pandangan politik, saling sikut di sosial media, semuanya berakhir menjadi lebih sejuk dan tenteram

Kesejukan juga meningkat saat Joko Widodo dan Ma' aruf Amin mengumumkan nama-nama menteri yang akan menemani perjalanan lima tahun periode masa jabatan. Prabowo Subianto yang terpilih sebagai menteri menjadi salah satu faktor kesejukan politik di Indonesia mulai terhembus. Selain itu, kabinet baru Joko Widodo dan Ma'aruf Amin yang diberi nama Indonesia Maju ini juga berisi sekitar 45 persen kalangan politik dan 55 persen kalangan profesional dan nonpolitik. Pemilihan komposisi ini mengurangi ketegangan karena dinilai melibatkan partisipasi masyarakat secara luas.

Beberapa profesional yang dipilih terdengar familiar dan dekat dengan masyarakat. Nama-nama yang terpilih antara lain adalah Nadiem Anwar Makarim, Wishnutama Kusubandio, dan Erick Thohir. Ketiga orang tersebut dikenal masyarakat sebagai pengusaha dan paling mengejutkan saat terpilih sebagai menteri. Pemilihan ketiga menteri tersebut didasarkan atas keinginan Presiden Joko Widodo dan wakil presiden Ma'aruf Amin untuk memunculkan representatif generasi milenial yang memiliki pengalaman untuk melakukan inovasi (www.bbc.com/ indonesia). Ketiga tokoh yang dikenal masyarakat tersebut menjadi nilai lebih sehingga masyarakat tidak merasa asing dengan menteri yang memimpin di Indonesia.

Ketiga menteri yang dikenal oleh masyarakat tersebut tampaknya masih diberikan kesempatan untuk tetap memberikan kesan dekat dengan masyarakat. Hal ini dapat dilihat melalui pementasan drama yang ketiganya dijadikan sebagai tokoh dalam pementasan tersebut. Ketiganya di dalam pementasan makin terlihat dekat dengan adanya lawakan-lawakan yang mereka sajikan dalam pementasan.

Tertawa memiliki salah satu fungsi sebagai pelancar komunikasi. Kesan komunikasi yang baik inilah yang dibangun dari upaya ketiga menteri tersebut untuk memerankan drama dan melontarkan lawakan. Ketiga menteri saat melawak tentu tidak semahir pelawak sungguhan. Namun, candaan yang dikeluarkan oleh mereka telah berhasil membuat penonton tertawa. Lawakan sederhana yang dibangun dari latar belakang mereka selama ini.

Kemampuan membuat lawakan yang dilontarkan oleh seluruh pemain pementasan dapat dijadikan sebagai referensi pembuatan bahan lawakan untuk orang awam. 
Dalam penelitian ini, akan dilihat struktur lawakan yang dilontarkan oleh pemain pementasan dan melihat adanya kesamaan teknik pembuatan komedi, yaitu memanfaatkan latar belakang dari ketiga menteri tersebut.

\section{LANDASAN TEORI}

Komedi atau humor adalah alat pencipta tawa. Kamus Besar Bahasa Indonesia menyebut komedi sebagai sesuatu yang lucu atau dalam arti lainnya sebagai keadaan yang menggelikan hati; kejenakaan; atau kelucuan(https://kbbi.kemdikbud.go.id/ entri/komedi). Komedi atau humor dapat ditemukan dalam media lakuan, grafis, dan literatur (Rahmanadji, 2007:218).

Kehadiran komedi di tengah masyarakat dapat muncul dari berbagai penjuru, termasuk juga pemerintahan. Pemerintah tentu memiliki tugas untuk menjalankan roda pemerintahan. Namun, pemerintah juga perlu dekat dengan masyarakat untuk memperlancar jalannya roda pemerintahan. Komedi adalah salah satu jalan pemerintah untuk dapat merawat komunikasi dengan masyarakat. Melihat usaha ketiga menteri untuk mendekatkan diri dengan masyarakat melalui media komedi dalam pentas drama merupakan upaya yang baik.

Cara pembangunan komedi dalam pentas drama "Prestasi Tanpa Korupsi" yang lebih menggunakan latar belakang ketiga menteri. Pembangunan komedi tersebut dapat dilihat sebagai sebuah ilmu untuk mereka yang awam dalam berkomedi. Penggunaan latar belakang sebagai bahan komedi akan dilihat menggunakan praanggapan pada ilmu prgamatik.

Pragmatik adalah ilmu tentang makna kontekstual. Hal tersebut disampaikan oleh Yule (2014:3-4) bahwa pragmatik adalah studi tentang makna yang disampaikan oleh penutur (penulis) dan ditafsirkan oleh pendengar (pembaca). Pragmatik erat hubungannya dengan pengetahuan dasar penutur atau pengalaman yang dialaminya dalam hidup untuk dapat mengartikan sesuatu. Djajasudarma (2012:48) menegaskan pragmatik sebagai ilmu bahasa yang mencakupi studi interaksi antara pengetahuan kebahasaan dan dasar pengetahuan tentang dunia yang dimiliki oleh pendengar atau pembaca.

Pragmatik juga berdiri sebagai sebuah ilmu yang berhubungan erat dengan konteks (Levinson dalam Rahardi, 2010:48). Putrayasa (2014:1) menyebut analisis pragmatik tidak dapat berlangsung bila tidak ada konteks di dalamnya. Konteks sangat dekat dengan kelancaran komunikasi, sebuah percakapan bisa saja tidak efektif bila salah satu dari pelibat cakap tidak memahami konteks percakapan (Djatmika, 2016:10).

Pragmatik sering disamaartikan dengan ilmu semantik. Kedua ilmu tersebut jelas berbeda. Semantik memerlakukan makna sebagai hubungan yang melibatkan dua segi (dyadic) dan pragmatik memerlakukan makna sebagai suatu hubungan yang melibatkan tiga segi (triadic) (Leech dalam Nadar, 2013:2). Sederhananya, Putra (2019: 157) membedakan keduanya dengan semantik mengkaji tentang makna literal sedangkan pragmatik mengkaji tentang maksud atau makna yang terikat konteks.

Praanggapan adalah satu bagian dari ilmu pragmatik. Praanggapan atau presupposisi adalah suatu asumsi yang dibangun oleh penutur sebelum menghasilkan tuturan (Yule, 2014:42-43). Praanggapan tersebut hadir dipikiran para penutur dan juga mitra tutur. Asumsi tersebut dibangun dari pengetahuan umum yang terbangun di masyarakat yang berkaitan dengan kemampuan penafsiran otomatis terhadap sesuatu yang tidak tertulis dan tidak terucap (Yule, 2014:146). 


\section{METODE PENELITIAN}

Penelitian ini bersifat kualitatif deskriptif. Penelitian kualitatif artinya penelitian ini akan menjelaskan fenomena yang akan diteliti dalam melalui pengumpulan data yang juga sedalam-dalamnya (Hariwijaya, 2007:85-86). Data merupakan fenomena lingual khusus yang mengandung dan berkaitan langsung dengan masalah yang dimaksud (Sudaryanto, 2015:6). Data yang digunakan dalam penelitian ini adalah tuturan pemain pentas drama "Prestasi Tanpa Korupsi" yang menghasilkan lawakan dan berhasil mendapatkan respon tertawa dari penonton. Pentas "Prestasi Tanpa Korupsi” dilaksakanan pada 9 Januari 2019. Data dikumpulkan dengan menyaksikan rekaman pertunjukan pentas "Prestasi Tanpa Korupsi" yang diunggah oleh sekretariat kepresidenan pada akun sosial media Youtube. Data diambil dengan melihat respon penonton yang menyaksikan secara langsung pertunjukkan tersebut. Data komedi tersebut kemudian disajikan dalam bentuk tulis dan dianalisis dengan teori yang telah dipaparkan sebelumnya.

\section{HASIL DAN PEMBAHASAN}

Pentas drama "Prestasi Tanpa Korupsi" dilaksanakan untuk memperingati Hari Anti Korupsi. Pentas drama tersebut diperankan oleh lima pemain yang tiga di antaranya adalah menteri. Ketiga menteri tersebut adalah Nadiem Makarim, Erick Thohir, dan Wishnutama. Kedua pemeran lainnya, yaitu Bedu dan Sogi yang merupakan seorang aktor serta komedian panggung. Penelitian ini akan melihat latar belakang ketiga menteri yang dijadikan sebagai bahan komedi. Pola pembangunan komedi yang sederhana melalui latar belakang dapat diimitasi oleh masyarakat yang awam dalam dunia komedi. Selanjutnya, tokoh ditandai dengan siswa 1 diperankan Nadiem Makarim; siswa 2 diperankan
Sogi; siswa 3 diperankan Wishnutama; siswa 4 diperankan Bedu; dan tukang bakso (T. Bakso) diperankan Erick Thohir. Pemaparan komedi yang menjabarkan latar belakang menteri dipaparkan berikutnya.

\section{Nadiem Makarim}

Nadiem Makarim ditetapkan sebagai Menteri Pendidikan dan Kebudayaan. Sebelum menjabat sebagai menteri Pendidikan dan Kebudayaan, beliau adalah CEO dari aplikasi transportasi daring, Gojek. Latar belakang Nadiem Makarim sebagai seorang menteri Pendidikan dan Kebudayaan menjadi bahan materi komedi pada data dialog sebagai berikut.

\section{(1)}

Siswa 1 : Maaf bang, kalau ada tanda seru enggak perlu pakai titik! Sama tanda serunya satu aja, enggak usah lima, maaf ye!

T. Bakso: Nah! Tuh (melihat Sogi), gara-gara elu!

Siswa 2 : Loh, kok gara-gara saya Bang?

T. Bakso: Gue diomelin sama temen elu. Bahasa gue dikoreksi, gayanya udah kaya menteri pendidikan aje.

(Ketawa dan Tepuk Tangan Penonton)

Data (1) tersebut menunjukkan bahwa ada usaha untuk menyinggung Nadiem Makarim yang berperan sebagai anak SMA adalah seorang Menteri Pendidikan dan Kebudayaan. Materi komedi yang terdapat pada data (1) ini berangkat dari praanggapan masyarakat yang terbangun atas pengetahuan umumnya mengenai Nadiem Makarim yang didaulat sebagai Menteri Pendidikan dan Kebudayaan. Pranggapan masyarakat lalu diperluas dengan pengetahuan mengenai Kementerian Pendidikan dan Kebudayaan yang memiliki berbagai tugas dan fungsi. Salah satu tugas dan fungsi Kementerian Pendidikan dan Kebudayaan adalah menjaga bahasa Indonesia sebagai 
bahasa negara. Tugas dan fungsi mengenai bahasa ditugaskan pada Badan Pengembangan dan Pembinaan Bahasa serta UPT balai/kantor bahasa yang tersebar di berbagai provinsi di Indonesia.

Pembangunan komedi pada data (1) diawali dari tuturan siswa 1 (Nadiem Makarim) yang menyanggah tuturan tukang bakso (Erick Thohir), "Maaf bang, kalau ada tanda seru, enggak perlu pakai titik, sama tanda serunya satu aja, enggak usah lima, maaf ya!". Tuturan tersebut menjadi pemicu komedi latar belakang yang dituturkan oleh tukang bakso.

"Gayanya udah kaya menteri pendidikan aje." Tuturan tersebut menghasilkan tawa penonton. Komedi tersebut menutupi pengetahuan masyarakat yang mengetahui bahwa Nadiem Makarim adalah benar aslinya seorang Menteri Pendidikan dan Kebudayaan.

Latar belakang Nadiem Makarim yang dijadikan bahan komedi pada pentas "Prestasi Tanpa Korupsi" adalah latar belakangnya sebagai seorang pendiri perusahaan transportasi daring, yaitu Gojek. Perusahaan Gojek bergerak di bidang transportasi dan juga jasa lainnya yang berkaitan. Hanya saja, masyarakat lebih mengetahui bahwa ojek dengan sistem daring yang paling melekat pada perusahaan tersebut. Latar belakang Nadiem Makarim sebagai seorang mantan pemilik Gojek juga dijadikan bahan komedi pada data berikut.

(2)

Siswa 4 : Eh, lu minggir lu. Lu, enggak tau gue? Gue ni anak orang kaya nih. Gue tau lu siapa! Lu yang sekolah tiap hari naik ojek kan lo?

Siswa 1 : Maaf kak!

(Ketawa penonton)

Praanggapan yang digunakan dalam pembanguna komedi pada data (2) ini adalah pengetahuan masyarakat mengenai Nadiem Makarim sebagai seorang mantan CEO Gojek. Fokus bidang usaha Nadiem Makarim sendiri adalah berkaitan dengan penyediaan layanan ojek. Tuturan yang berisi komedi ada pada siswa 4 (Bedu), "Lu yang sekolah tiap hari naik ojek kan lo?"

Tuturan siswa 4 (Bedu) berhasil membuat penonton tertawa. Pengetahuan penonton terhadap latar belakang Nadiem Makarim sebelum menjadi menteri, membuat komedi ini berhasil.

\section{Erick Thohir}

Erick Thohir ditetapkan sebagai menteri Badan Usaha Milik Negara. Erick Thohir sebelumnya dikenal sebagai seorang pengusaha dan pernah memiliki saham klub sepak bola Italia, Inter Milan.

Erick Thohir sebagai seorang menteri BUMN, dikenal dengan kinerja yang baik. Sebelum pementasan berlangsung, kementerian BUMN melalui Erick Thohir melakukan pembersihan di tubuh BUMN yang ada di Indonesia. Pergantian direktur utama pada beberapa BUMN, serta yang terakhir berhasil mengumumkan atas terungkapnya kasus penyelundupan pada perusahaan milik negara, yaitu Garuda Indonesia. Kasus penyelundupan motor Harley Davidson serta beberapa sepeda mewah yang menyeret nama Direktur Utama Garuda Indonesia. Kasus tersebut ramai dibicarakan oleh masyarakat.

Praanggapan yang berdasarkan pengetahuan umum tentang Menteri BUMN yang mengungkap kasus Harley Davidson ini menjadi bahan komedi dalam pentas "Prestasi Tanpa Korupsi". Data yang berkaitan dengan praanggapan tersebut ada pada berikut ini.

(3)

$$
\begin{gathered}
\text { T. Bakso : Ini yang katanya } \\
\text { anak bos? }
\end{gathered}
$$

Siswa 3 : Iya nih 
Siswa 4 : Iya saya

Siswa 2 : Ini nih, ini bang!

T. Bakso : Ini kan?

Siswa 3 : Sikat bang! Kayak itu, Menteri BUMN tuh! Nyikat-nyikatin kaga beres!

(Ketawa penonton)

Tuturan siswa 3 (Wishnutama), "Sikat bang! Kayak itu, Menteri BUMN tuh! Nyikat-nyikatin kaga beres!" Tuturan ini berhasil menyulut tawa dan tepuk tangan penonton. Komedi ini berhasil karena penonton memiliki praanggapan umum mengenai pengetahuan masyarakat terhadap Erick Thohir. Erick Thohir diketahui sering mengusut dan membongkar permasalahan korupsi di BUMN yang ada di Indonesia. Tuturan ini lalu diperkuat sendiri oleh Erick Thohir serta menggunakan praanggapan umum yang lain. Data dapat dilihat berikut ini.

(4)

T. Bakso : Nih toh!

Siswa 4 : Iye

T. Bakso : Jangan mentangmentang anak bos, malah manfaatin fasilitas, relasi.

Namanya nepotisme. Enggak boleh! Entar kalau lu udah gede, terus jadi dirut, malah nitip barangbarang lu!

Siswa 3 : Harley Bang!

Siswa 2 : Harley!

(Ketawa penonton)

Komedi pada data (4) ini, tukang bakso (Erick Thohir) yang lebih menjadi penutur yang menghasilkan tawa. Tuturan tersebut pada "Entar kalau lu udah gede, terus jadi dirut, malah nitip barang-barang lu!" Tuturan tersebut memperkuat latar bela- kang tentang Erick Thohir sebagai seorang menteri BUMN yang baru saja mengungkap kasus korupsi di tubuh perusahan BUMN, Garuda Indonesia.

Tuturan "Harley" oleh siswa 2 dan siswa 3 menyelimuti praanggapan tentang pengetahuan umum masyarakat berkaitan kasus yang baru saja dibuka oleh Erick Thohir. Kasus penyelundupan Harley Davidson. Kasus ini ramai di masyarakat dan jadi bahan diskusi secara bebas.

\section{Wishnutama Kusubandio}

Wishnutama Kusubandio dikenal masyarakat sebagai Direktur Trans Media serta pendiri NET Mediatama Televisi. Wishnutama semakin dikenal setelah berhasil menjadi Pengarah Kreatif pada perhelatan pembukaan dan penutupan Asean Games 2018. Wishnutama dipilih sebagai menteri Pariwisata dan Ekonomi Kreatif. Kementerian Pariwisata dan Ekonomi Kreatif merupakan Kementerian yang baru dibentuk dan diwujudkan pada pemerintahan Presiden Joko Widodo dan Wakil Presiden Ma' aruf Amin periode 2019-2024. Kementerian ini adalah penggabungan antara Kementerian Pariwisata dan Badan Ekonomi Kreatif.

Latar belakang Wishnutama sebagai seorang menteri Pariwisata dijadikan sebagai bahan komedi pada data sebagai berikut.

(5)

Siswa 4 : Tam, lama banget lu, Tam!

Siswa 3 : Gini, gue lagi liat-liat nih. Ini bagus, yang entu bagus, gue jadi binggung yang mana nih?

Siswa 4 : Ah, elu liat brosur jalan-jalan mulu. Lu mau jadi menteri pariwisata lu?

(Ketawa penonton)

Data (5) memperlihatkan sebuah komedi yang dibangun dari praanggapan tentang 
pengetahuan umum mengenai latar belakang Wishnutama yang dipilih sebagai menteri Pariwisata. Komedi itu dibangun dari tuturan siswa 4 (Bedu) "Ah, elu liat brosur jalan-jalan mulu. Lu mau jadi menteri pariwisata?".

Tuturan siswa 4 (Bedu) berhasil mendapatkan tawa penonton. Hal ini karena komedi dari tuturan tersebut berhasil menyampaikan tentang latar belakang Wishnutama. Masyarakat mengetahui bahwa benar Wishnutama akhirnya menjadi menteri Pariwisata.

Latar belakang Wishnutama sebagai menteri Ekonomi Kreatif juga diperlihatkan pada data lainnya.

(6)

Siswa 3 : Nih, gue kan senior di sini! Gue kasi tau lu pade dari pada lu korupsi, korupsi waktu, korupsi uang, mendingan lu pada mikirin halhal yang positif, yang inovatif, yang kreatif, biar bangga nih sekolah kite!

Siswa 2 : Wah, bagus-bagus!

T. Bakso: Wueh, cakep! Cocoknya jadi Menteri Ekonomi Kreatif!

(Ketawa penonton)

Data (6) menggunakan praanggapan tentang latar belakang Wishnutama sebagai menteri Ekonomi Kreatif. Tuturan yang mengandung praanggapan tersebut terdapat pada tuturan tukang bakso "Wueh, cakep! Cocoknya jadi menteri ekonomi kreatif!"

Tuturan tukang bakso (Erick Thohir) tersebut menggunakan latar belakang Wishnutama sebagai seorang menteri Ekonomi Kreatif. Data komedi berikutnya memperkuat latar belakang Wishnutama sebagai menteri pariwisata dan ekonomi kreatif.
(7)

Siswa 3 : Tadi Bedu bilang menteri pariwisata, sekarang ekonomi kreatif. Abang nih!

T. Bakso : Ya digabungin aja! Menteri Pariwisata dan Ekonomi Kreatif!

\section{(Tepuk tangan)}

Data (7) memperlihatkan pembangunan komedi yang berasal dari pengetahuan masyarakat mengenai latar belakang Wishnutama Kusubandio. Tuturan tukang bakso (Erick Thohir) "Ya digabungin aja! Menteri Pariwisata dan Ekonomi Kreatif". Tuturan tersebut berhasil secara komedi dan sekaligus mengungkapkan tentang adanya kementerian yang digabung pada masa pemerintahan Joko Widodo dan Ma'aruf Amin periode 2019-2024.

Komedi yang terbangun pada pementasan drama "Prestasi Tanpa Korupsi" menunjukkan adanya kesederhanaan pola. Komedi terbangun melalui latar belakang masa lalu ketiga menteri. Cara berkomedi yang sederhana seperti pada pementasan ini dapat digunakan oleh masyarakat luas untuk kepentingan komunikasi. Masyarakat juga tetap memperhatikan sikap santun saat berkomedi, sehingga tidak ada yang merasa disudutkan dalam komedinya.

\section{PENUTUP}

Pementasan drama "Prestasi Tanpa Korupsi" hadir sebagai cara pemerintah untuk menunjukkan bahwa pemerintahan Presiden Joko Widodo dan Wakil Presiden Ma'aruf Amin menolak adanya praktik korupsi. Hal ini dituangkan dalam cara yang ringan, yaitu melalui pementasan drama. Pemain dari drama "Prestasi Tanpa Korupsi" juga didominasi oleh menteri yang telah dikenal di masyarakat. Harapan untuk dapat selalu dekat dengan masyarakat ter- 
tuang dalam komedi yang dibangun dalam pementasan.

Komedi dalam pementasan ini terbilang sederhana. Dari ketujuh data yang dipaparkan pada bagian pembahasan dapat dilihat bahwa semua bahan komedi menghasilkan tawa di dalam pementasan, hanya diambil dari praanggapan tentang latar belakang ketiga menteri. Komedi yang diambil hanya sekadar mematahkan pengetahuan umum masyarakat bahwa ketiganya adalah menteri serta latar belakang lainnya.

Pementasan drama "Prestasi Tanpa Korupsi" beserta dengan bahan komedi yang menyertainya dapat dijadikan sebuah pembelajaran. Pembangunan komedi dapat dibangun dari hal sederhana dan dari hal yang ada di sekitar kita. Komedi dalam pementasan ini menunjukkan bahwa komedi dapat dibangun dari sesuatu yang melekat pada manusia sehingga semua orang dapat mencoba untuk membangun komedi secara sederhana yang berasal dari dirinya sendiri.

\section{DAFTAR PUSTAKA}

Cahyono, Rudi Tri, Niken Iriani LNH, dan Sri Lestari. 2002. "Kecenderungan Somatisasi Ditinjau dari Sense of Humor dan Kemampuan Menyelesaikan Masalah". Jurnal Indigenous 6 (2): $160-$ 167. Surakarta: Universitas Muhammadiyah Surakarta.

Djajasudarma, T. Fatimah. 2012. Wacana $\mathcal{E}$ Pragmatik. Bandung: PT. Refika Aditama. Djatmika. 2016. Mengenal Pragmatik Yuk!?. Yogyakarta: Pustaka Pelajar.
Hariwijaya, M. 2007. Metodologi dan Penulisan Skripsi Tesis dan Disertasi: Untuk ilmu Sosial dan Humaniora. Yogyakarta: Parama Ilmu.

https://kbbi.kemdikbud.go.id/entri/komedi. Diakses 24 Januari, 2020.

Nadar, F.X. 2013. Pragmatik \& Penelitian Pragmatik. Yogyakarta: Graha Ilmu.

Putra, Pandu Pratama. 2019. "Pelanggaran Muka Positif dan Negatif Pengguna Bahasa Kutai" pada Kolom Komentar Akun Instagram Info_Kukar. Dalam Masfufah (Ed.). Kearifan Lokal Kalimantan Timur:Bunga Rampai Hasil Penelitian Kebahasaan dan Kesastraan: 154-174. Samarinda: Kantor Bahasa Kalimantan Timur.

Putrayasa, Ida Bagus. 2014. Pragmatik. Yogyakarta: Graha Ilmu.

Rahardi, R. Kunjana. 2010. Pragmatik: Kesantunan Imperatif Bahasa Indonesia. Jakarta: Penerbit Erlangga.

Rahmanadji, Didiek. 2007. 'Sejarah, Teori, Jenis, dan Fungsi Humor'. Jurnal Bahasa dan Seni 35 (2): 214-221. Malang: Universitas Negeri Malang.

www.bbc.com/indonesia. "Nadiem Makarim, Wishnutama, dan Erick Thohir: Para Calon Menteri Muda di Kabinet Jokowi yang Diharap Membawa Perubahan". Diakses 24 Januari, 2020.

www.kanal.co. "10 Manfaat Ketawa”. Diakses 27 Januari, 2020.

Yule, George. 2014. Pragmatik. Yogyakarta: Pustaka Pelajar. 